\title{
Estrogen Biphasically Modifies Hypothalamic GABAergic Function Concomitantly with Negative and Positive Control of Luteinizing Hormone Release
}

\author{
Edward J. Wagner, Oline K. Rønnekleiv, Martha A. Bosch, and Martin J. Kelly \\ Department of Physiology and Pharmacology, Oregon Health Sciences University, Portland, Oregon 97201
}

The principal role of estrogen is its control of the female ovulatory cycle via negative and positive feedback on gonadotropin secretion. However, a detailed, cohesive picture of how the steroid specifically regulates the excitability of hypothalamic neurons involved in the central control of gonadotropin secretion is still emerging. Here, we used an ovariectomized female guinea pig model to test the hypothesis that estrogen acts on GABAergic neurons in the preoptic area (POA) to elicit a biphasic profile of luteinizing hormone (LH) secretion. Intracellular electrophysiological recordings revealed that estradiol benzoate (EB; $25 \mu \mathrm{g}$, s.c.) decreased the hyperpolarizing response of GABAergic neurons to the $\mathrm{GABA}_{B}$ receptor agonist baclofen 24 $\mathrm{hr}$ after treatment. This effect of $\mathrm{GABA}_{\mathrm{B}}$ receptor stimulation in unidentified POA neurons was still depressed $42 \mathrm{hr}$ after EB administration. By the use of a ribonuclease protection assay, however, EB reduced glutamic acid decarboxylase mRNA ex- pression $42 \mathrm{hr}$ but not $24 \mathrm{hr}$ after its administration. Thus, estrogen attenuated the autoinhibition of GABAergic POA neurons during the initial LH suppressive (i.e., negative feedback) phase and subsequently reduced GABAergic function during the LH surge (i.e., positive feedback). These studies demonstrate that the effects of estrogen on hypothalamic GABAergic neurons coincide with the inhibitory and stimulatory actions, respectively, of the steroid on LH secretion. Furthermore, the data provide novel insights into the mechanism by which estrogen regulates hypothalamic GABAergic neurons, which are critical for the biphasic modulation of LH release observed over the course of the female ovulatory cycle.

Key words: luteinizing hormone; estrogen; GABA; preoptic area; electrophysiology; glutamic acid decarboxylase; in situ hybridization
It is well recognized that estrogen controls the mammalian female reproductive cycle by both negative and positive feedback actions on gonadotropin [i.e., follicle-stimulating hormone and luteinizing hormone $(\mathrm{LH})]$ secretion, the specific nature of which varies among mammalian species. In females that exhibit a luteal phase, estrogen suppresses gonadotropin release from the anterior pituitary throughout the vast majority of the reproductive cycle (Tsai and Yen, 1971; Yen and Tsai, 1971; Yamaji et al., 1972; Condon et al., 1988; Witkin et al., 1994) that, for guinea pigs and primates, lasts 14-18 d (considerably longer than that observed for other commonly used rodent species) and 1 month, respectively (Knobil, 1974; Terasawa and Wiegand, 1978; Witkin et al., 1991). During the mid-to-late follicular phase, however, plasma estrogen levels gradually rise, resulting in the preovulatory LH surge (Yen and Tsai, 1972; Knobil, 1974; Condon et al., 1988).

It is primarily accepted that for guinea pigs and primates, the dual estrogenic feedback on LH secretion occurs via alterations in the excitability of gonadotropin-releasing hormone $(\mathrm{GnRH})$ neurosecretory cells located in the preoptic area (POA) and mediobasal hypothalamus (MBH) (Silverman et al., 1979; Goldsmith et al., 1990; Witkin et al., 1991; King et al., 1998). GnRH neurons do

\footnotetext{
Received Sept. 18, 2000; revised Dec. 5, 2000; accepted Jan. 3, 2001.

The experiments described in this study were supported by Public Health Service Grants NS35944, NS38809, and DA00192 (Research Scientist Development Award to M.J.K.). We thank Jason T. Deignan and Barry Naylor for their technical assistance and Dr. David Grandy for his critical evaluation of this manuscript.

Correspondence should be addressed to Dr. Edward J. Wagner, Department of Physiology and Pharmacology, L334, Oregon Health Sciences University, 3181 Southwest Sam Jackson Park Road, Portland, OR 97201. E-mail: wagnere@ohsu.edu.

Copyright (C) 2001 Society for Neuroscience 0270-6474/01/212085-09\$15.00/0
}

not express estrogen receptors (Watson et al., 1992; Herbison et al., 1995; Sullivan et al., 1995), which implies that afferent neural substrates are the primary targets of estrogen action. Two prominent, estrogen-sensitive inhibitory neurotransmitter systems that provide synaptic input to GnRH neurons are GABA and opioid peptides such as $\beta$-endorphin and dynorphin (Chronwall, 1985; Leranth et al., 1985; Morrell et al., 1985; Hammer et al., 1994; Herbison, 1997). The GABAergic neurons most likely are local intrinsic interneurons (Brown et al., 1994) and interact with opioid systems to inhibit LH release (Masotto et al., 1989; Brann et al., 1992; Donoso et al., 1992). On the other hand, there is considerable evidence that GABA directly inhibits GnRH and thereby LH secretion (Leranth et al., 1985; Lagrange et al., 1995). Despite extensive research, however, we still lack a clear picture of precisely how estrogen alters hypothalamic GABAergic neurotransmission to control GnRH and thereby $\mathrm{LH}$ secretion.

Because of the noted similarities in the reproductive cycle of guinea pigs and primates, the former makes an ideal animal model for the study of mammalian female reproductive physiology. Therefore, we used the ovariectomized female guinea pig to test the hypothesis that estrogen biphasically regulates LH secretion in part via temporally synchronized effects on hypothalamic GABAergic neurons. To this end, we examined estrogenic modulation of the $\mathrm{GABA}_{\mathrm{B}}$ receptor-mediated activation of an inhibitory $\mathrm{K}^{+}$conductance and the expression of the biosynthetic enzyme for GABA, glutamic acid decarboxylase (GAD), in the POA. The effects of the $\mathrm{GABA}_{\mathrm{B}}$ receptor agonist baclofen (Bowery, 1989) and the antagonist CGP 52,432 (Lanza et al., 1993) were examined in intracellular recordings made from GABAergic POA neurons subsequently confirmed by combined histofluores- 
cence and in situ hybridization for $\mathrm{GAD}_{65}$. GAD expression in POA neurons was determined with in situ hybridization and ribonuclease protection assay. The results reveal that estrogen attenuates GABAergic autoinhibition and POA GAD expression in a temporal pattern that coincides with the steroid's negative and positive feedback on gonadotropin secretion, respectively. Moreover, these data indicate that POA GABAergic neurons are a key link in the estrogenic regulation of the ovulatory cycle.

\section{MATERIALS AND METHODS}

Animals and treatments. Female Topeka guinea pigs (470-660 gm) were obtained from our institutional breeding facility and maintained under constant temperature $\left(72.4 \pm 0.1^{\circ} \mathrm{F}\right.$ ) and light (on between 06:30 and 20:30 hr). Animals were housed individually, with food and water provided ad libitum. They were ovariectomized under ketamine and xylazine anesthesia (33 and $6 \mathrm{mg} / \mathrm{kg}$, respectively, s.c.) 5-17 d before experimentation and given either estradiol benzoate (EB; $25 \mu \mathrm{g}$, s.c.) or its sesame oil vehicle $(0.1 \mathrm{ml}$, s.c.) 24 or $42 \mathrm{hr}$ before experimentation. Serum estrogen concentrations were determined by radioimmunoassay from trunk blood collected on the day of experimentation. This treatment regimen produced physiological levels of $17 \beta$-estradiol (vehicle, undetectable; $24 \mathrm{hr}, 351.1 \pm 31.3 \mathrm{pg} / \mathrm{ml} ; 42 \mathrm{hr}, 66.5 \pm 11.2 \mathrm{pg} / \mathrm{ml} ; n=11-24)$ within the range of values observed over the course of the female menstrual cycle (Yen and Tsai, 1972; Knobil, 1974). All animal procedures described in this study are in accordance with institutional guidelines based on National Institutes of Health standards.

Drugs. All drugs were purchased from Sigma (St. Louis, MO) unless otherwise specified. EB was dissolved in sesame oil to a concentration of $250 \mu \mathrm{g} / \mathrm{ml}$. Tetrodotoxin (TTX) was dissolved in Milli-Q $\mathrm{H}_{2} \mathrm{O}$ and further diluted with $0.1 \%$ acetic acid (final concentration, $1 \mathrm{mM} ; \mathrm{pH} 4-5$ ). ( \pm )Baclofen was dissolved in $0.1 \mathrm{~N} \mathrm{HCl}$ to a concentration of $40 \mathrm{~mm}$. [3-[[(3,4dichlorophenyl)methyl]amino]propyl](diethoxymethyl) phosphinic acid (CGP 52,432; provided by A. Sedlacek, CIBA-GEIGY AG, Basel, Switzerland) was dissolved in Milli-Q $\mathrm{H}_{2} \mathrm{O}$ to a concentration of $1 \mathrm{~mm}$. Aliquots of the stock solutions were stored as appropriate until needed.

Serum LH measurement. Serial blood samples were collected from indwelling catheters implanted via the jugular vein into the right atrium as described previously (Condon et al., 1988). Catheter implantation was performed on animals anesthetized with the ketamine and xylazine mixture 2 weeks after ovariectomy. The sampling period ranged from 2 $\mathrm{hr}$ before to $48 \mathrm{hr}$ after an intravenous injection of $17 \beta$-estradiol $\left(\mathrm{E}_{2}\right)$. Serum LH levels were determined in duplicate with a heterologous radioimmunoassay using an anti-ovine $\mathrm{LH}$ antisera (GDN-15; kindly provided by Dr. Gordon Niswender) as reported previously (Condon et al., 1988).

Tissue preparation. For electrophysiological studies, on the day of experimentation the animal was decapitated, its brain was removed from the skull, and the hypothalamus was dissected. Four coronal slices $(350-450 \mu \mathrm{m})$ through the POA were cut using a vibratome. The slices were transferred to a multiwell auxiliary chamber containing oxygenated $\left(95 \% \mathrm{O}_{2}\right.$ and $5 \% \mathrm{CO}_{2}$ ) artificial CSF (aCSF; see below) and kept there until electrophysiological recording.

For in situ hybridization, the brain was sliced into coronal blocks using a brain slicer (EM Corporation, Chestnut Hill, MA). The POA block (3 $\mathrm{mm}$ ) and $\mathrm{MBH}$ blocks $(2 \mathrm{~mm}$ ) were fixed in $4 \%$ paraformaldehyde for 6 $\mathrm{hr}$, soaked in $20 \%$ sucrose solution, frozen, and sectioned at $15 \mu \mathrm{m}$. For the ribonuclease protection assay the POA and $\mathrm{MBH}$ were dissected from their respective blocks using a dissecting microscope. The tissue was quickly frozen, and total RNA was extracted using Trizol Reagent (Life Technologies, Gaithersburg, MD).

Electrophysiology. Intracellular recordings in current clamp were performed as described previously (Kelly et al., 1992). Briefly, slices were maintained in a chamber perfused with warmed $\left(35^{\circ} \mathrm{C}\right)$, oxygenated aCSF containing the following constituents, in mM: $\mathrm{NaCl}, 124 ; \mathrm{KCl}, 5$; $\mathrm{NaH}_{2} \mathrm{PO}_{4}, 2.6$; dextrose, 10; HEPES, $10 ; \mathrm{MgSO}_{4}, 2$; and $\mathrm{CaCl}_{2}$, 2. In some experiments, slice preparation and subsequent slice incubation before being transferred to the recording chamber used aCSF containing $1 \mathrm{mM} \mathrm{CaCl}_{2}$. Artificial CSF and all drug solutions were perfused via a peristaltic pump at a rate of $1.5 \mathrm{ml} / \mathrm{min}$. Drug solutions were prepared in $20 \mathrm{ml}$ syringes by diluting the appropriate stock solution with aCSF, and the flow was controlled via a three-way stopcock. Microelectrodes $(100-$ $225 \mathrm{M} \Omega$ ) were assembled from borosilicate glass pipettes and filled with a $3 \%$ biocytin solution in $1.75 \mathrm{M} \mathrm{KCl}$ and $0.025 \mathrm{M}$ Tris, $\mathrm{pH}$ 7.4.
After successful impalement, slices were perfused with $2 \mu \mathrm{M}$ TTX (6 min) to block spontaneous firing and supplemented with $1 \mu \mathrm{M}$ TTX in all subsequent drug solutions. Agonist dose-response relationships were generated by applying a dose of baclofen until a new steady-state membrane potential $\left(\mathrm{V}_{m}\right)$ had been obtained (4-7 min). After drug discontinuation, the $\mathrm{V}_{m}$ eventually returned to its predrug resting level, and an incrementally higher dose of baclofen was administered, until finally a maximum steady-state hyperpolarization $\left(\Delta \mathrm{V}_{\max }\right)$ was reached. Estimates of the baclofen $\mathrm{EC}_{50}$ and $\Delta \mathrm{V}_{\max }$ were obtained from single neurons via the logistic equation:

$$
\Delta V_{\max }=100 *\left([\text { baclofen }]^{n} /\left([\text { baclofen }]^{n}+\mathrm{EC}_{50}{ }^{n}\right)\right),
$$

fitted by computer (SigmaPlot; Jandel Scientific, San Rafael, CA) from the data points. The pharmacodynamics sometimes were reevaluated after the drug washout in the presence of CGP 52,432 (1 $\mu \mathrm{M})$. Estimates of the $K_{i}$ for CGP 52,432 were derived from the logistic equation:

$\Delta V_{\max }=100 *\left([\text { baclofen }]^{n} /\left([\text { baclofen }]^{n}+\mathrm{EC}_{50}{ }^{n *}\right.\right.$

$\left.\left.\left(1+\left([\text { CGP } 52,432]^{n} / K_{i}^{n}\right)\right)\right)\right)$

fitted by computer from the data points.

Prebaclofen current-voltage $(I / V)$ relationships were established by giving hyperpolarizing and depolarizing current pulses $(0.2 \mathrm{~Hz} ; 1 \mathrm{sec})$ and monitoring the voltage deflections. After the maximal response to baclofen $(10-100 \mu \mathrm{M})$ reached steady state, the $\mathrm{V}_{m}$ was then returned to its original resting state by injecting positive current, and a second $I / V$ was established. Cell conductance was analyzed by linear regression as the slope of the $I / V$ plots between -60 and $-80 \mathrm{mV}$ and between -100 and $-130 \mathrm{mV}$. The baclofen-induced conductance change $(\Delta g)$ was determined by subtracting the predrug from the postdrug $I / V$ slopes.

Guinea pig $G A D_{67}$ clone. A fragment of the guinea pig $\mathrm{GAD}_{67}$ gene was cloned using reverse transcription (RT)-PCR. Oligonucleotide primers $100 \%$ homologous to human $\mathrm{GAD}_{65}$ were designed (5'-primer, base pairs 671-692; 3'-primer, base pairs 1007-1028 of the human sequence). These primers were used to clone both $\mathrm{GAD}_{65}$ [as reported previously (Wagner et al., 1999)] and $\mathrm{GAD}_{67}$. Primer synthesis by Life Technologies included at the $5^{\prime}$-end of both primers a 12 base extension of deoxy-UMP residues used with the PCR cloning kit CloneAmp pAMP10 System (Life Technologies). The $\mathrm{GAD}_{67}$ fragment was amplified from $100 \mathrm{ng}$ of total RNA extracted from the guinea pig POA using RT-PCR (GeneAmp kit; Perkin-Elmer, Foster City, CA). The human GAD $3^{\prime}$-primer was used for the cDNA first-strand synthesis. Reverse transcription was performed for $15 \mathrm{~min}$ at $42^{\circ} \mathrm{C}$. PCR was conducted for 35 cycles of denaturation $\left(92^{\circ} \mathrm{C} ; 1 \mathrm{~min}\right)$, annealing $\left(55^{\circ} \mathrm{C} ; 2 \mathrm{~min}\right)$, and extension $\left(72^{\circ} \mathrm{C} ; 3 \mathrm{~min}\right)$, with a 3 min final extension. The $358 \mathrm{bp}$ PCR product was subcloned into the pAMP10 vector using the CloneAmp (Life Technologies) system, and sequencing confirmed the product to be $\mathrm{GAD}_{67} \mathrm{cDNA}$.

In situ hybridization. In situ hybridization was performed using the $\mathrm{GAD}_{65}$ and $\mathrm{GAD}_{67}$ riboprobes. Slides were post-fixed in fresh $4 \%$ paraformaldehyde (40 min), rinsed with Sorensen's phosphate buffer, and treated with Proteinase-K $\left(1.0 \mu \mathrm{g} / \mathrm{ml} ; 2 \mathrm{~min} ; 37^{\circ} \mathrm{C}\right)$. All sections were then treated ( $3 \mathrm{~min}$ ) with $0.1 \mathrm{M}$ triethanolamine, followed by $0.25 \%$ acetic anhydride in $0.1 \mathrm{M}$ triethanolamine $(10 \mathrm{~min})$. Thereafter, the sections were rinsed in $2 \times \mathrm{SSC}$ and hybridized $\left(56-58^{\circ} \mathrm{C} ; \geq 18 \mathrm{hr}\right)$ as described previously (Fang and Rønnekleiv, 1999). Sections were rinsed in $2 \times$ SSC (30 min) on a shaker, reacted with RNase $\left(20 \mu \mathrm{g} / \mathrm{ml} ; 30 \mathrm{~min} ; 37^{\circ} \mathrm{C}\right)$, and sequentially rinsed in $1 \times, 0.5 \times$, and $0.25 \times \operatorname{SSC}\left(\sim 55^{\circ} \mathrm{C}\right)$. Slides were finally washed $\left(30 \mathrm{~min} ; 65^{\circ} \mathrm{C}\right)$ in $0.1 \times \mathrm{SSC}$ containing $1.0 \mathrm{~mm}$ dithiothreitol. The sections were dehydrated in increasing concentrations of ethanol and together with autoradiographic ${ }^{14} \mathrm{C}$-microscales (Amersham, Arlington Heights, IL) were exposed to hyperfilm- $\beta_{\max } \mathrm{x}$-ray film (NEN, Boston, MA) for 5-6 d at $4^{\circ} \mathrm{C}$. Slides were then dipped in Kodak NTB-2 emulsion and exposed for up to $16 \mathrm{~d}$ at $4^{\circ} \mathrm{C}$. Sections were evaluated and photographed under dark-field illumination using a Zeiss microscope configured with a dark-light attachment (Foster, Inc.).

Ribonuclease protection assay. The antisense $\mathrm{GAD}_{65}$ and $\mathrm{GAD}_{67}$ riboprobes were labeled by in vitro transcription with $\left[{ }^{32} \mathrm{P}\right] \mathrm{rUTP}$ and were purified using the Fullengther Preparative Gel Apparatus (Biokey American Instrument, Aloha, OR). The GAD probes were incubated with $3 \mu \mathrm{g}$ of total RNA or $125-4000 \mathrm{fg}$ of sense standard RNA overnight at $45^{\circ} \mathrm{C}$. Hybridization was terminated by ribonuclease digestion; the protected fragments were loaded onto an acrylamide gel and exposed to film for visualization. Quantification was performed using a phosphorimager 


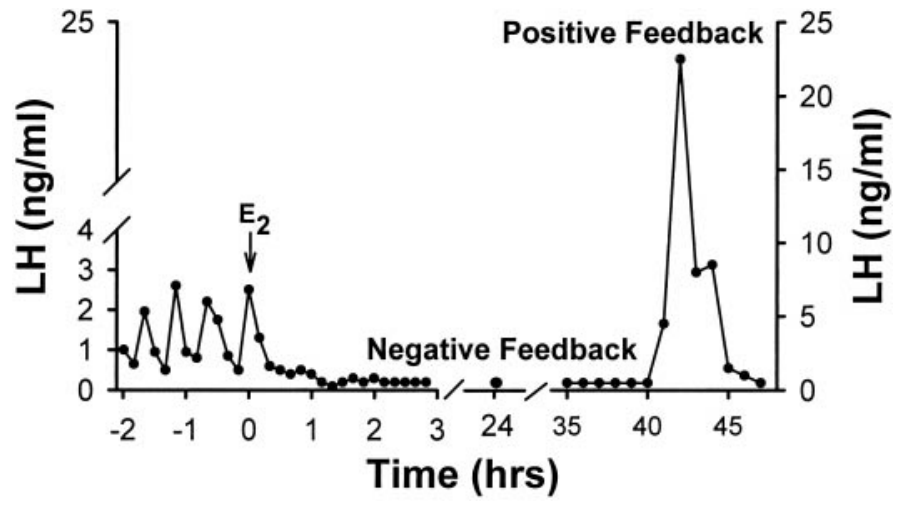

Figure 1. Estrogen produces both negative and positive feedback on gonadotropin secretion. Representative composite hormone profile based on serial blood samples taken from ovariectomized female guinea pigs. Filled circles represent plasma LH concentrations determined by radioimmunoassay at various time points before and after $E_{2}(25 \mu \mathrm{g})$ administration.

(Bio-Rad, Hercules, CA). Each GAD band was normalized with its corresponding cyclophilin band.

Cell phenotype identification. After electrophysiological recording, slices were fixed in $4 \%$ paraformaldehyde in $0.03 \mathrm{M}$ Sorensen's phosphate buffer $\left(90-180 \mathrm{~min} ; 4^{\circ} \mathrm{C}\right)$ and then soaked overnight in buffer containing $20 \%$ sucrose. All solutions were prepared with diethylpolycarbonatetreated Milli- $\mathrm{Q} \mathrm{H}_{2} \mathrm{O}$ and molecular-grade reagents. Frozen slices were sectioned at $20 \mu \mathrm{m}$ on a cryostat (Leitz Model 1720 Digital Cryostat), mounted on Superfrost-plus slides, and then washed $(5 \mathrm{~min})$ with $0.1 \mathrm{M}$ phosphate buffer. Streptavidin-Texas Red (Jackson ImmunoResearch, West Grove, PA), diluted with seaweed gelatin solution (Rönnekleiv et al., 1991) in the presence of RNAsin $(60 \mathrm{U} / \mathrm{ml})$ and sodium heparin $(1.25$ $\mathrm{mg} / \mathrm{ml})$, was then applied $(2 \mathrm{hr})$. The reaction was terminated by washing with $0.1 \mathrm{M}$ phosphate buffer. Biocytin-filled GABAergic neurons were identified by combined histofluorescence and in situ hybridization as described previously (Wagner et al., 1999).

Statistical analyses. Comparison between two groups was performed using either the Student's two-tailed $t$ test, the paired $t$ test, or the Mann-Whitney $U$ test. Comparisons between two or more groups were performed using a multifactorial ANOVA followed by the least significant difference (LSD) test. Differences were considered statistically significant if the probability of error was $<5 \%$.

\section{RESULTS}

\section{Animal model}

The dual feedback actions of estrogen on the reproductive axis of the female guinea pig are illustrated in Figure 1. Systemic $\mathrm{E}_{2}$ administration to ovariectomized animals results in a rapid inhibition of pulsatile LH secretion (negative feedback). This suppression lasts nearly $40 \mathrm{hr}$ and is immediately followed by a surge of $\mathrm{LH}$ release over and above that observed before $\mathrm{E}_{2}$ administration (positive feedback).

\section{Estrogen decreases the $\mathrm{GABA}_{B}$ response in POA neurons during negative feedback}

The potential for $\mathrm{GABA}_{\mathrm{B}}$ receptor involvement in this initial, negative feedback phase was evaluated via intracellular electrophysiological recording from POA neurons. As shown in Figure $2 a$, the $\mathrm{GABA}_{\mathrm{B}}$ receptor agonist baclofen elicited a dosedependent membrane hyperpolarization of POA neurons. Evaluation of the $I / V$ plot in Figure $2 b$ reveals that the baclofen response reversed polarity very near the Nernst equilibrium potential for $\mathrm{K}^{+}$. The baclofen-induced hyperpolarization was antagonized by CGP 52,432 (1 $\mu \mathrm{M})$ that was overcome by increasing concentrations of the agonist (Fig. 2c). This antagonism by CGP
52,432 produced a rightward shift in the agonist dose-response curve with an estimated $K_{i}$ of $64 \pm 7$ nм (Fig. $2 d$ ).

Compared with the dose-response relationships generated in POA neurons from vehicle-treated animals (Fig. 3a), those obtained from animals treated with EB $24 \mathrm{hr}$ before were markedly attenuated (Fig. 3b). Although EB did not affect baclofen potency, it decreased the hyperpolarization magnitude at all doses tested (Fig. 3c). This finding was corroborated by a parallel diminution in the baclofen-induced $\Delta g$ measured between -60 and $-80 \mathrm{mV}$ and between -100 and $-130 \mathrm{mV}$ (Fig. $3 d$ ). These effects of $\mathrm{EB}$ on the $\mathrm{GABA}_{\mathrm{B}}$ receptor-mediated response still persisted $42 \mathrm{hr}$ after administration $\left(\Delta \mathrm{V}_{\max }=8.2 \pm 1.3 \mathrm{mV} ; n=\right.$ $4 ; p<0.05)$.

\section{GABAergic neuronal distribution in the guinea pig hypothalamus}

GABAergic neurons express estrogen receptors, and GABA is arguably the predominant neurotransmitter in the hypothalamus (Decavel and van den Pol, 1990; Herbison, 1997). GAD is the rate-limiting enzyme for the production of GABA and is expressed in two forms, $\mathrm{GAD}_{65}$ and $\mathrm{GAD}_{67}$, derived from two genes (Martin and Rimvall, 1993). To study the distribution of GABAergic neurons in the guinea pig hypothalamus and to determine whether GABA synthesis is regulated by estrogen, we prepared specific PCR clones for $\mathrm{GAD}_{65}$ (Wagner et al., 1999) and $\mathrm{GAD}_{67}$. The guinea pig $\mathrm{GAD}_{65}$ mRNA sequence was 90 and $89 \%$ identical to corresponding sequences of human and rat $\mathrm{GAD}_{65}$ and 75 and $74 \%$ identical to human and rat $\mathrm{GAD}_{67}$, respectively. The guinea pig $\mathrm{GAD}_{67}$ mRNA sequence was 94 and $90 \%$ identical to corresponding sequences of human and rat $\mathrm{GAD}_{67}$, respectively, and $72 \%$ identical to human $\mathrm{GAD}_{65}$. As shown in Figure 4, the $\mathrm{GAD}_{65}$ riboprobe robustly labeled neurons throughout the rostrocaudal extent of the POA and $\mathrm{MBH}$. In the POA, the hybridization signal was particularly abundant in the anteroventral periventricular nucleus of the hypothalamus (AVPV) and the medial preoptic nucleus (MPN). In the MBH, high levels of $\mathrm{GAD}_{65}$ expression were observed in the dorsomedial hypothalamic nucleus (DMH), the arcuate nucleus (Arc), and the ventral premammillary nucleus (PMv). By the use of in situ hybridization analysis, $\mathrm{GAD}_{67}$ exhibited a similar mRNA distribution pattern (data not shown).

\section{Expression of $\mathrm{GAD}_{65}$ in electrophysiologically and immunocytochemically identified POA neurons}

The aforementioned observations render the GABAergic neuronal phenotype a likely target for the modulatory effect of $\mathrm{EB}$ on the $\mathrm{GABA}_{\mathrm{B}}$ receptor-mediated hyperpolarization. We therefore used $\mathrm{GAD}_{65}$ as a marker for post hoc identification after electrophysiological recording using combined histofluorescence and in situ hybridization. Examples of GAD-positive POA neurons from animals treated with either vehicle (Fig. $5 a, b$ ) or EB (Fig. 5c,d) $24 \mathrm{hr}$ before are shown in Figure 5. The $\Delta \mathrm{V}_{\max }$ for baclofen observed in the GABAergic cell from the EB-treated animal $(5.8 \mathrm{mV})$ was only $64 \%$ of that observed in the GABAergic cell from the vehicletreated animal $(9.0 \mathrm{mV})$. The majority $(62 \%)$ of POA neurons from EB-treated animals were GAD positive, and the reduction in the $\Delta \mathrm{V}_{\max }$ in these cells $(6.9 \pm 0.9 \mathrm{mV})$ was comparable with that observed in the population as a whole (see Fig. 3c).

\section{Estrogen decreases $\mathrm{GAD}_{65}$ and $\mathrm{GAD}_{67}$ mRNA levels at the time of positive feedback}

We used a sensitive ribonuclease protection assay (RPA) to quantify the levels of $\mathrm{GAD}_{65}$ and $\mathrm{GAD}_{67}$ mRNA in the guinea 
a

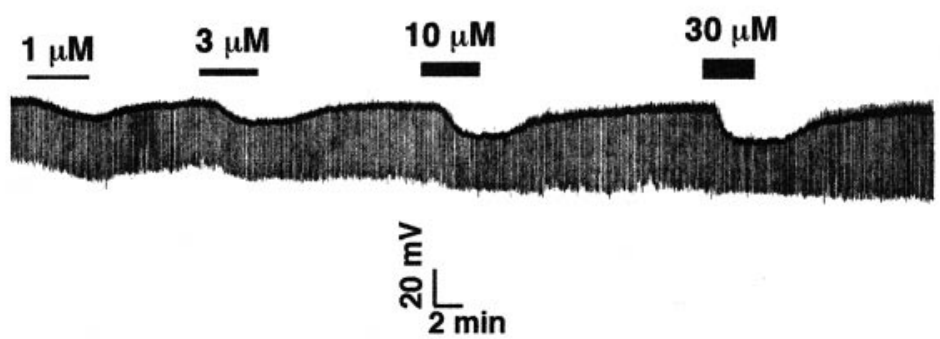

C +CGP 52,432(1 $\mu \mathrm{M})$

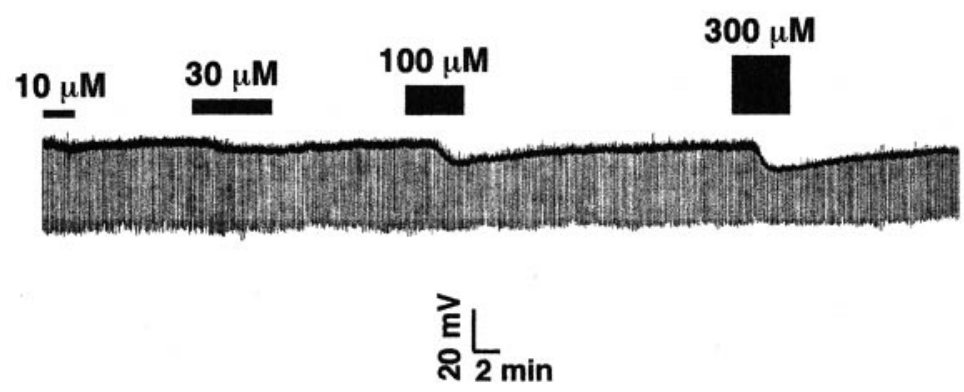

b

- control

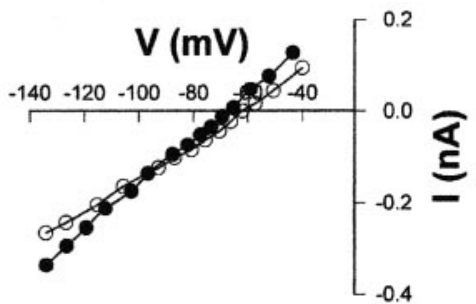

d

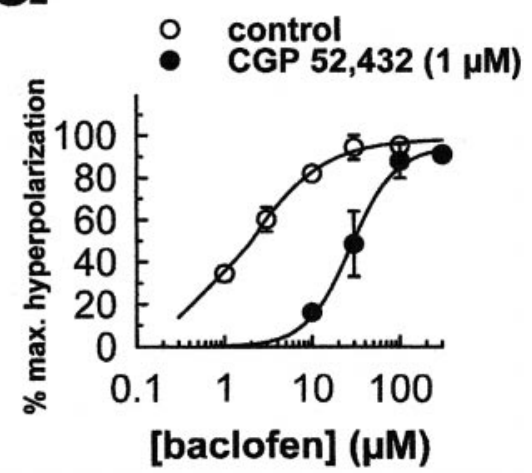

Figure 2. Stimulation of $\mathrm{GABA}_{\mathrm{B}}$ receptors inhibits POA neurons by activating a $\mathrm{K}^{+}$conductance. $a$, Successively increasing doses of baclofen $(1,3$, 10 , and $30 \mu \mathrm{M}$ ) hyperpolarized this POA neuron (resting $\mathrm{V}_{m}=-55 \mathrm{mV}$ ) at $8.5,11,16$, and $18 \mathrm{mV}$, respectively. $b$, An $I / V$ plot derived from a POA neuron just before (control; open circles) and near the end of the application of a maximal concentration of baclofen (100 $\mu \mathrm{M}$; filled circles) is shown. The reversal potential for the baclofen response was $-94 \mathrm{mV}$, and a $\Delta g$ of $0.67 \mathrm{nS}$ between -60 and $-80 \mathrm{mV}$ and a $\Delta g$ of $1.63 \mathrm{nS}$ between -100 and -130 $\mathrm{mV}$ were also observed. $c$, Dose-response relationship from the cell shown in $a$ is then generated in the presence of CGP $52,432(1 \mu \mathrm{M})$. Successively increasing doses of baclofen $(10,30,100$, and $300 \mu \mathrm{M})$ elicited hyperpolarizations of $2.5,4.5,11$, and $12.5 \mathrm{mV}$, respectively. $d$, Composite baclofen dose-response curves in the absence (open circles) and presence ( filled circles) of CGP 52,432 (1 $\mu \mathrm{M})$ are shown. Cells were perfused with successively higher concentrations of baclofen $(1,3,10,30,100$, and $300 \mu \mathrm{M} ; 4-7 \mathrm{~min} / \mathrm{dose} ; n=2-10)$. Symbols represent means, and vertical lines are 2 SEMs of the baclofen-induced hyperpolarization normalized to the $\Delta \mathrm{V}_{\max }$. Before CGP 52,432, the mean baclofen $\mathrm{EC}_{50}$ value was $2.3 \pm 0.5 \mu \mathrm{M}$, whereas in the presence of CGP 52,432, the $\mathrm{EC}_{50}$ was shifted to $33.0 \pm 10.0 \mu \mathrm{M}$. The estimated $K_{i}$ for CGP 52,432 was $64.0 \mathrm{~nm}$. BAC, Baclofen.

pig hypothalamus. Figure $6 a$ illustrates the levels of $\mathrm{GAD}_{65}$ and $\mathrm{GAD}_{67}$ mRNA found in hypothalamic RNA extracts from vehicle-treated animals. Both $\mathrm{GAD}_{65}$ and $\mathrm{GAD}_{67}$ mRNAs were found in highest quantities in the POA. However, GAD $_{67}$ mRNA was significantly more abundant throughout the hypothalamus in comparison with $\mathrm{GAD}_{65}$ (Fig. 6a).

Finally, we evaluated the effect of EB on the expression of both $\mathrm{GAD}_{65}$ and $\mathrm{GAD}_{67}$ in the hypothalamus using the sensitive RPA for mRNA quantification. In the POA, EB was without effect on the expression of either isoform at $24 \mathrm{hr}$ (data not shown) but decreased the expression of both $\mathrm{GAD}_{65}$ and $\mathrm{GAD}_{67}$ mRNA 42 hr after its administration (Fig. 6b,c). By contrast, both $\mathrm{GAD}_{65}$ and $\mathrm{GAD}_{67}$ mRNA expression in the $\mathrm{MBH}$ were unaltered over the same time period. Taken together, these data demonstrate that EB attenuates the efficacy with which GABAergic ligands activate $\mathrm{GABA}_{\mathrm{B}}$ receptors to inhibit GABAergic POA neurons and increases the inhibitory tone provided by these neurons during negative feedback. Subsequently the expression of the biosynthetic enzyme for GABA decreases, which would decrease inhibitory tone in this region during positive feedback.

\section{DISCUSSION}

The results of the present study reveal that estrogen decreases the $\mathrm{GABA}_{\mathrm{B}}$ receptor-mediated autoinhibition of GABAergic POA neurons. In addition, estrogen induces an apparent decrease in the subsequent ability of these neurons to synthesize GABA. These conclusions are based on the observations that (1) estrogen reduces the hyperpolarization and the underlying $\mathrm{K}^{+}$conductance observed in POA neurons, the majority of which are GAD positive, in response to a given dose of $\mathrm{GABA}_{\mathrm{B}}$ receptor agonist and (2) the steroid decreases mRNA levels for both $\mathrm{GAD}_{65}$ and $\mathrm{GAD}_{67}$ in the POA as determined by ribonuclease protection assay.

\section{Somatodendritic $\mathrm{GABA}_{\mathrm{B}}$ autoreceptors couple to a $\mathrm{K}^{+}$ conductance in GABAergic POA neurons}

The coupling of postsynaptic $\mathrm{GABA}_{\mathrm{B}}$ receptors to a $\mathrm{K}^{+}$conductance in POA neurons is consistent with what we have shown previously in hypothalamic Arc neurons (Kelly et al., 1992; Wagner et al., 1999) and with that observed in many other brain regions (for review, see Misgeld et al., 1996). Moreover, the resultant hyperpolarization observed in the present study is an- 
a vehicle

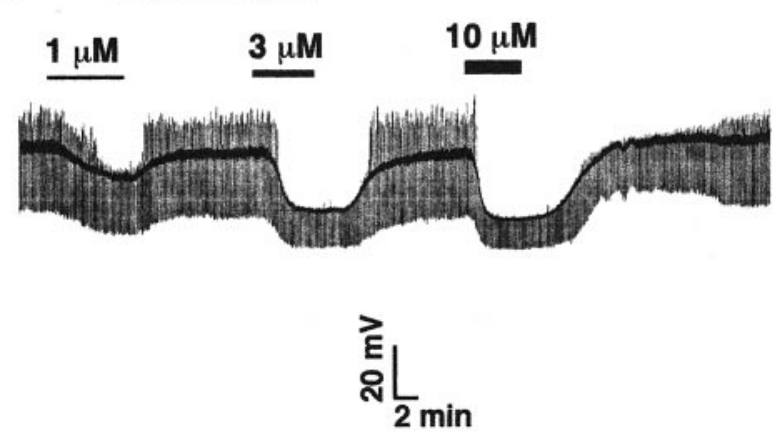

0 estradiol benzoate (25 $\mu \mathrm{g} ; 24 \mathrm{hr})$

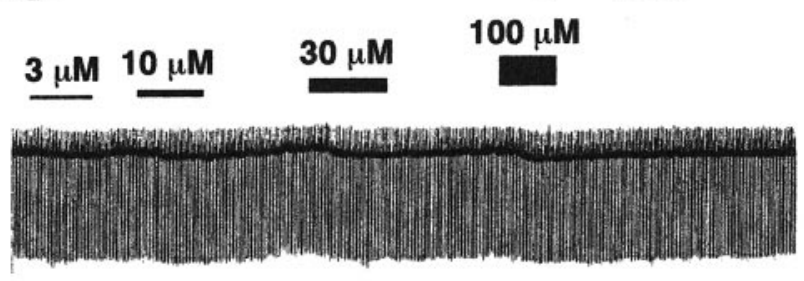

온
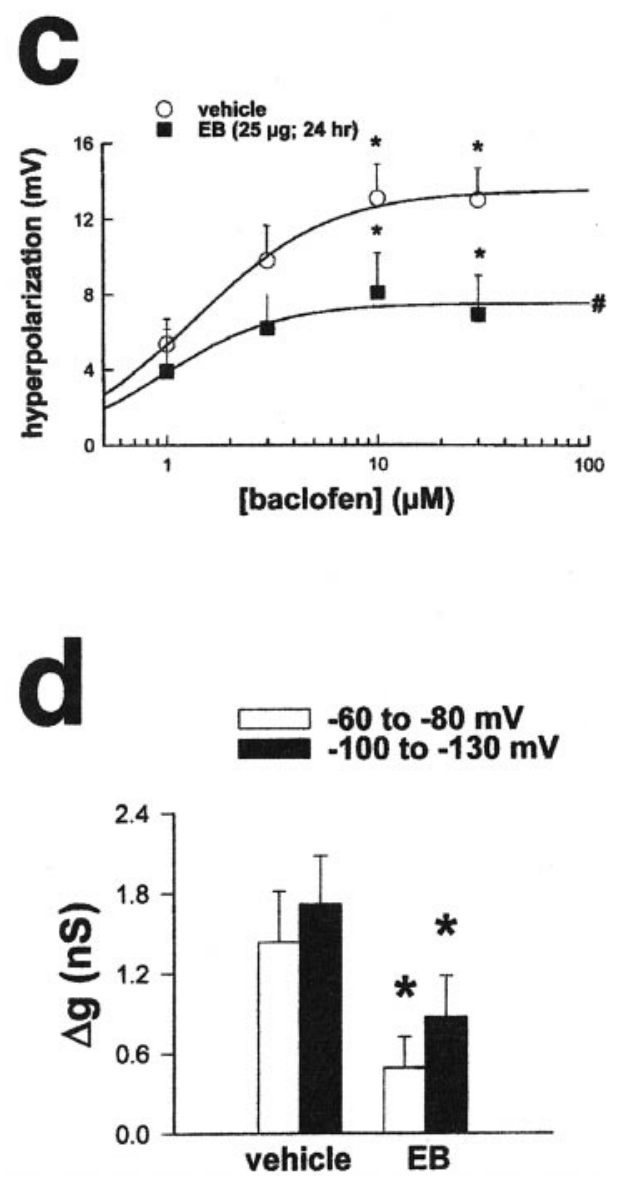

Figure 3. Estrogen attenuates the efficacy of $\mathrm{GABA}_{\mathrm{B}}$ receptor-mediated neurotransmission in the POA 24 hr after its administration. $a$, Successively increasing doses of baclofen $(1,3$, and $10 \mu \mathrm{M})$ hyperpolarized this POA neuron from a vehicle-treated animal (resting $\left.\mathrm{V}_{m}=-45 \mathrm{mV}\right) 10,22.5$, and 25.5 $\mathrm{mV}$, respectively. The upward deflection represents the return of low-threshold spikes and/or action potentials (truncated) seen during the later stages of drug washout. $b$, Successively increasing doses of baclofen $(3,10,30$, and $100 \mu \mathrm{M})$ hyperpolarized this POA neuron (resting $\left.\mathrm{V}_{m}=-50 \mathrm{mV}\right)$ from an EB-treated $(25 \mu \mathrm{g} ; 24 \mathrm{hr})$ animal by $1.5,2.5,3$, and $4 \mathrm{mV}$, respectively. $c$, Composite dose-response curves from recordings of POA neurons obtained from vehicle- and EB-treated animals are shown. Cells were perfused with successively higher concentrations of baclofen $(1,3,10$, and $30 \mu \mathrm{M} ; 4-7$ $\mathrm{min} /$ dose; $n=2-10$ ). Symbols represent means, and vertical lines are $1 \mathrm{SEM}$ of the hyperpolarizations elicited by a given concentration of baclofen. The $\Delta \mathrm{V}_{\max }$ obtained via logistic fit for POA neurons from vehicle-treated animals was $13.5 \mathrm{mV}$, whereas that obtained for POA neurons from EB-treated animals was $7.5 \mathrm{mV}$. *, Hyperpolarizations obtained with 10 and $30 \mu \mathrm{M}$ baclofen that are significantly different (multifactorial ANOVA and LSD; $p<$ 0.05 ) from those obtained with 1 or $3 \mu \mathrm{M}$ baclofen are shown. \#, Hyperpolarizations of POA neurons obtained from EB-treated animals are significantly lower (multifactorial ANOVA and LSD; $p<0.05$ ) than those obtained from vehicle-treated animals at all doses tested. $d$, Composite bar graph illustrates the baclofen-induced $\Delta g$ in POA neurons from vehicle- and EB-treated animals $(n=5-8)$. Columns represent means, and vertical lines are 1 SEM of the baclofen-induced $\Delta g$ estimated by linear regression between -60 and $-80 \mathrm{mV}$ and between -100 and $-130 \mathrm{mV}$. ${ }^{*}$, Values of $\Delta g$ obtained in POA neurons from EB-treated animals that are significantly different (multifactorial ANOVA and LSD; $p<0.05$ ) from those obtained from vehicle-treated controls are shown.

tagonized by CGP 52,432 with an estimated $K_{i}(64 \mathrm{~nm})$ comparable with that of similar reports from other areas (Lanza et al., 1993; Bon and Galvan, 1996). These receptors have long been thought to serve as autoreceptors, inhibiting GABA release via presynaptic inhibition of $\mathrm{Ca}^{2+}$ channels (Bowery, 1989; Misgeld et al., 1996). However, activation of postsynaptic GABA $_{B}$ receptors in the presence of TTX, which inhibits synaptic transmission, results in a robust hyperpolarization of GABAergic Arc neurons (Wagner et al., 1999). Qualitatively, we observed an identical response under the same conditions from GABAergic POA neurons in the present study. Thus, the excitability of hypothalamic GABAergic neurons is regulated by the activation of both somatodendritic $\mathrm{GABA}_{\mathrm{B}}$ receptors and those on presynaptic nerve terminal membranes. The source of endogenous neurotransmitter activating the somatodendritic $\mathrm{GABA}_{\mathrm{B}}$ receptor may arise from a presynaptic bouton making contact with the GABAergic POA neuron in a GABA-GABA synapse (Decavel and van den
Pol, 1992; Commons et al., 1999). Alternatively, it could come from the GABAergic POA neurons themselves, contained within recurrent collaterals making synaptic contact with their own perikarya as has been shown in the Arc (Yagi and Sawaki, 1975; Sawaki and Yagi, 1976; van den Pol and Cassidy, 1982).

\section{Estrogen uncouples postsynaptic $\mathrm{GABA}_{\mathrm{B}}$ receptors from their effector $\mathrm{K}^{+}$channels in POA neurons, manifest by a reduction in agonist efficacy}

In view of its fundamental role in controlling the reproductive axis, it should not be surprising that estrogen exerts a multitude of effects on hypothalamic GABAergic neurons. These neurons express estrogen receptors and concentrate radiolabeled estradiol (Herbison, 1997). In addition, the steroid elicits ultrastructural changes in GABAergic neurons and alters synaptic morphology between GABAergic nerve terminals and their respective postsynaptic contacts, including GnRH neurons (Leranth et al., 

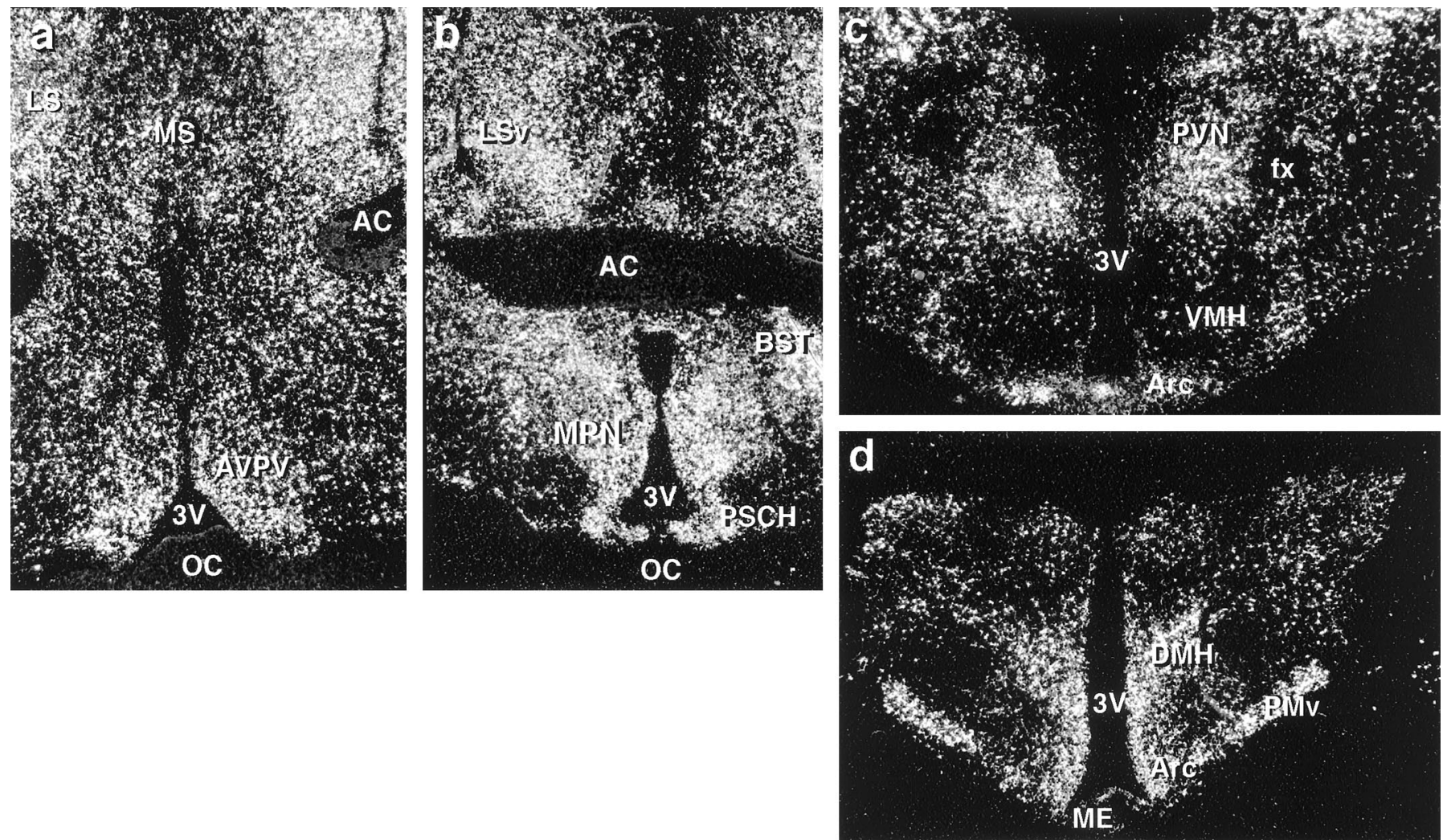

Figure 4. Distribution of $\mathrm{GAD}_{65}$ in the guinea pig hypothalamus. $a$, $b$, Dark-field photomicrographs that illustrate the distribution of GAD 65 in the rostral $(a)$ and caudal $(b)$ POA. $c, d$, Dark-field photomicrographs of coronal sections through the MBH from rostral to caudal illustrating the distribution of $\mathrm{GAD}_{65}$ mRNA. $A C$, Anterior commissure; $B S T$, bed nucleus of the stria terminalis; $f x$, fornix; $L S$, lateral septum; $L S v$, lateral septum (ventral part); $M E$, median eminence; MS, medial septum; $O C$, optic chiasm; $P S C H$, suprachiasmatic preoptic nucleus; $P V N$, paraventricular nucleus; $V M H$, ventromedial nucleus of the hypothalamus; $3 \mathrm{~V}$, third ventricle.

1991; Párducz et al., 1993; Naftolin et al., 1996). Furthermore, in Arc neurons estrogen uncouples postsynaptic $\mathrm{GABA}_{\mathrm{B}}$ and $\mu$-opioid receptors from their effector $\mathrm{K}^{+}$channels, resulting in a reduction in agonist potency (Kelly et al., 1992). This receptor/effector uncoupling is caused by the estrogen receptor-mediated activation of an intracellular protein kinase A (PKA) pathway (Lagrange et al., 1997). Because the response to both $\mathrm{GABA}_{\mathrm{B}}$ and $\mu$-opioid receptor agonists is negatively modulated by estrogen to the same extent, we believe that PKA phosphorylates critical protein(s) common to both of these signaling pathways (for review, see Kelly and Wagner, 1999). In the present study postsynaptic $\mathrm{GABA}_{\mathrm{B}}$ receptors on POA GABAergic neurons were uncoupled from their effector system not by a reduction in potency but by an attenuation in the efficacy of $\mathrm{GABA}_{\mathrm{B}}$ receptor-mediated neurotransmission. This would indicate a downregulation of $\mathrm{GABA}_{\mathrm{B}}$ receptors. Future studies will determine whether activation of kinase pathways is involved in mediating estrogen's negative modulation of the $\mathrm{GABA}_{\mathrm{B}}$ receptor-mediated response in these neurons.

\section{$\mathrm{GABA}_{\mathrm{B}}$ receptor/effector uncoupling caused by estrogen in GABAergic POA neurons reduces autoinhibition, which increases the inhibitory tone onto GnRH neurons during negative feedback}

The steroid-induced, dampened responsiveness of GABAergic POA neurons to $\mathrm{GABA}_{\mathrm{B}}$ receptor activation likely serves to reduce the extent of autoinhibition, thereby increasing neuro- transmitter release from these neurons (Fig. 7). Indeed, synaptic levels of GABA in the POA of ovariectomized rats, measured by microdialysis or push-pull perfusion, are elevated as early as $1 \mathrm{hr}$ after systemic injection of $\mathrm{E}_{2}$ (Herbison et al., 1991; Jarry et al., 1995). Moreover, this is analogous to the steroid regulation of hypothalamic GABAergic neuronal activity observed in the male rat, in which antiandrogen treatment and castration both decrease POA GABA turnover, the latter of which is prevented by testosterone replacement (Grattan and Selmanoff, 1994; Grattan et al., 1996a). This androgen effect may be caused by the aromatization of testosterone to estrogen in the POA (Roselli et al., 1987).

The results of the present study, in conjunction with available anatomical (Leranth et al., 1985; Naftolin et al., 1996) and functional (Masotto et al., 1989; Herbison et al., 1991; Brann et al., 1992; Donoso et al., 1992; Jarry et al., 1995) evidence, suggest that GABA plays a critical role in the steroid-induced negative feedback of gonadotropin secretion. The increase in the synaptic concentrations of GABA in the POA produced by estrogen occurs concomitantly with a decrease in plasma levels of $\mathrm{LH}$ (Herbison et al., 1991; Jarry et al., 1995). The estrogen-induced suppression of $\mathrm{LH}$ secretion observed in the present study persists well beyond $24 \mathrm{hr}$ after administration (Fig. 1), which suggests that the reduced autoinhibition of POA GABAergic neurons and hence the increased GABA release are sustained over a considerable period of time. In support of this idea, we have observed that POA neurons from ovariectomized animals treated with $\mathrm{EB} 42 \mathrm{hr}$ before also exhibit an attenuated $\mathrm{GABA}_{\mathrm{B}}$ response magnitude. 

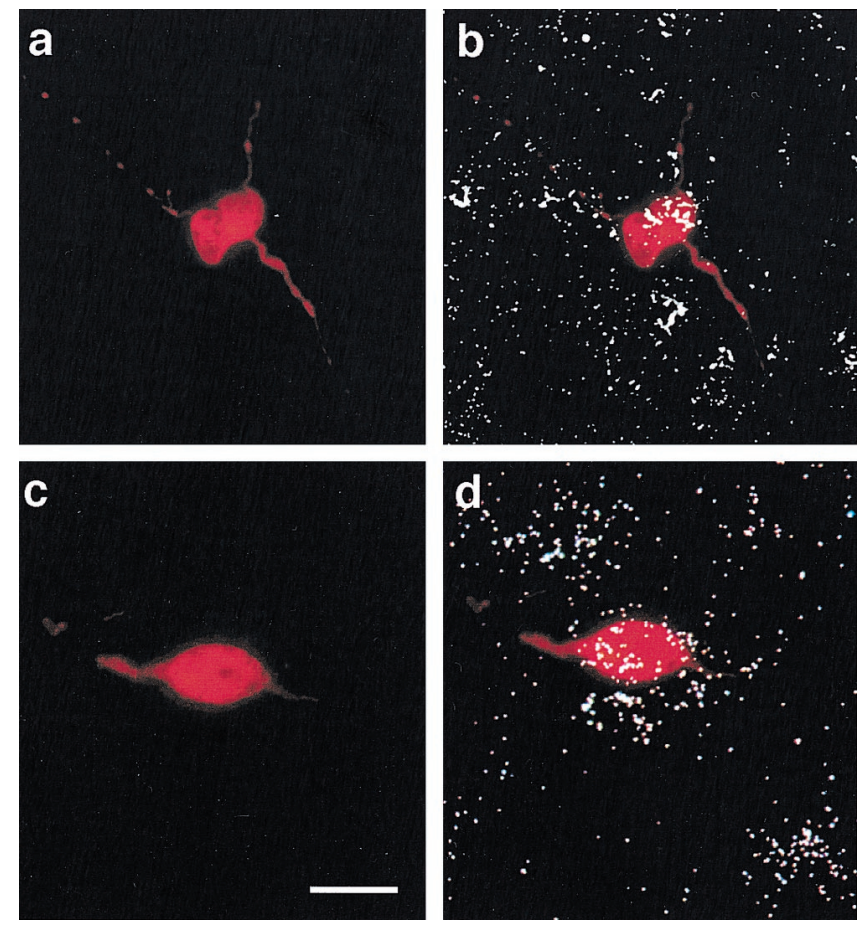

Figure 5. GABAergic POA neurons are identified using combined histofluorescence and in situ hybridization for $\mathrm{GAD}_{65}$ after electrophysiological recording. $a$, Photomicrograph of the biocytin-streptavidin-Texas Red fluorescent labeling of a recorded cell from a vehicle-treated animal. $b$, An overlay of the fluorescent labeling in $a$ and the hybridization signal that clearly illustrates the double labeling for $\mathrm{GAD}_{65} . c$, Photomicrograph of the biocytin-streptavidin-Texas Red fluorescent labeling of a recorded POA neuron from an EB-treated $(25 \mu \mathrm{g} ; 24 \mathrm{hr}$ ) animal. $d$, An overlay of the fluorescent labeling in $c$ and the hybridization signal illustrating the double labeling for $\mathrm{GAD}_{65}$. Scale bar, $\sim 15 \mu \mathrm{m}$ (for all photomicrographs).

\section{Estrogen subsequently decreases GAD expression in the POA, and the resultant decrease in GABA levels helps promote the preovulatory LH during positive feedback}

Estrogen also produced a latent decrease in the expression of both $\mathrm{GAD}_{65}$ and $\mathrm{GAD}_{67}$ in the POA $42 \mathrm{hr}$ after its administration. This is consistent with the reduction in mRNA levels for both isoforms reported during the proestrus phase of the estrous cycle in the diagonal band of Broca of female rats, which was associated with a decrease in GABA turnover (Grattan et al., 1996b). In addition, GABA release in the POA of ovariectomized rats decreases beginning several hours before the onset, and continues through the ascending phase, of the estrogen-induced LH surge (Jarry et al., 1992).

Although GABAergic neurons express estrogen receptors, there are a number of reports showing that estrogen affects neither the enzymatic activity of GAD nor its transcription in rat POA (for review, see Herbison, 1997). However, our results suggest that the steroid decreases the transcription of both isoforms in the female guinea pig. On the other hand, an increase in GABAergic neuronal activity such as that which might occur via depolarization or, in the case of the present study, a relief from autoinhibition increases the synthesis of GABA that is known to competitively inhibit GAD (Martin and Rimvall, 1993). Thus, a prolonged increase in neuronal activity attributed to an estrogen-induced decrement in

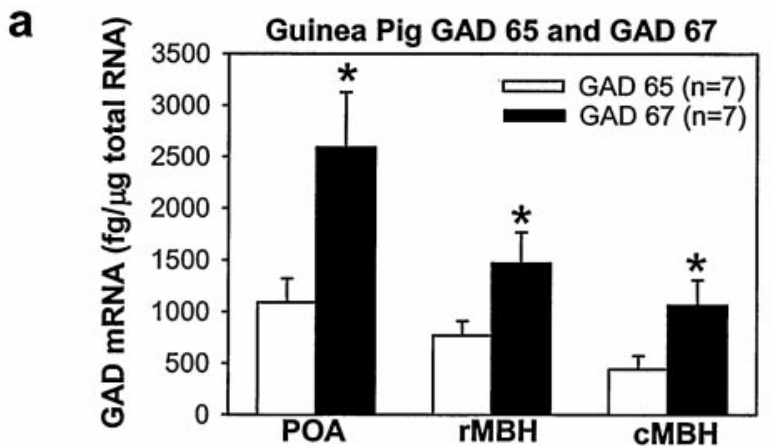

b
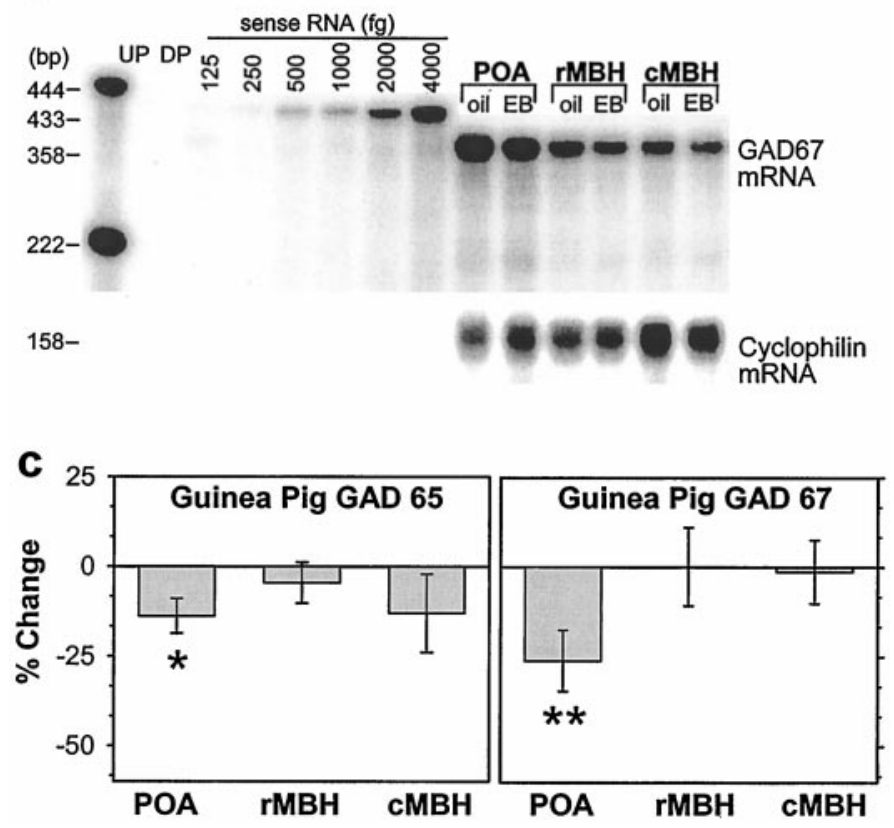

Figure 6. Estrogen produces a subsequent decrease in the POA expression of $\mathrm{GAD}_{67}$ and $\mathrm{GAD}_{65} 42 \mathrm{hr}$ after its administration. $a$, Distribution and quantitative analysis using a sensitive ribonuclease protection assay of $\mathrm{GAD}_{65}$ and $\mathrm{GAD}_{67}$ mRNA in the POA and $\mathrm{MBH}$ obtained from female guinea pigs. *, Denotes the levels of $\mathrm{GAD}_{67}$ that are significantly greater (Student's $t$ test; $p<0.05$ ) than those obtained for $\mathrm{GAD}_{65} . b$, A representative ribonuclease protection assay of total RNA ( $3 \mu \mathrm{g} /$ lane) from vehicle- and EB-treated ( $25 \mu \mathrm{g} ; 42 \mathrm{hr}$ ) animals illustrating the levels of $\mathrm{GAD}_{67}$ mRNA detected in the POA and the rostral $(r)$ and caudal $(c)$ $\mathrm{MBH}$. Sense RNA (125-4000 fg) was used to construct a standard curve. $c$, Quantitative analysis of $\mathrm{GAD}_{65}$ (left) and $\mathrm{GAD}_{67}$ (right) mRNA in hypothalamic brain tissue obtained from vehicle- and EB-treated animals. Bands were normalized to their corresponding cyclophilin band and quantified from their respective sense mRNA standard curves. Columns represent means, and vertical lines are 2 SEMs of the EB-induced percent change in the $\mathrm{GAD}_{65}$ and $\mathrm{GAD}_{67}$ levels with respect to those observed in vehicle-treated animals. *, Denotes a significant change (paired $t$ test; $p<$ 0.05 ) in the level of $\mathrm{GAD}_{65}$ caused by EB relative to that observed in the POA of vehicle-treated controls. **, Denotes a significant change (paired $t$ test; $p<0.01)$ in the level of $\mathrm{GAD}_{67}$ caused by $\mathrm{EB}$ relative to that observed in the POA of vehicle-treated controls. $D P$, Digested probe; $U P$, undigested probe.

$\mathrm{GABA}_{\mathrm{B}}$ receptor-mediated autoinhibition of GABAergic POA neurons may account, in part, for the decrease in GAD expression via end-product inhibition. Such a reduction in the capacity of GABAergic POA neurons to produce the inhibitory neurotransmitter would likely facilitate the generation of the estrogen-induced LH surge (Fig. 7). 
a 24h Estrogen: Negative Feedback

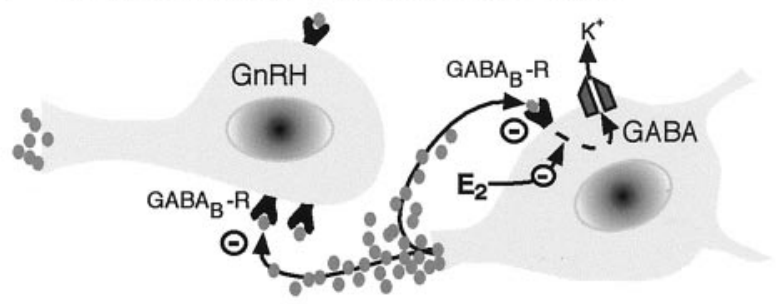

b 42h Estrogen: Positive Feedback

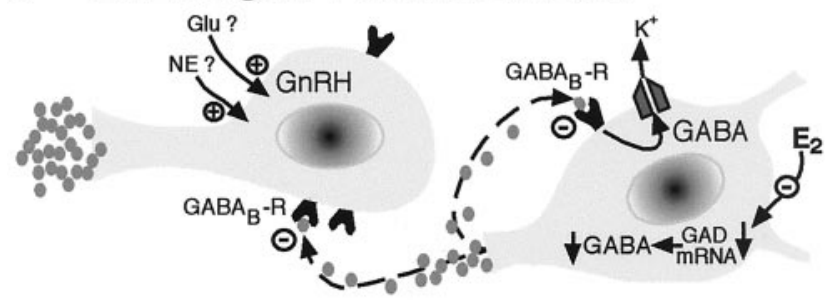

Figure 7. Schematic representation illustrating the biphasic central feedback actions of estrogen on the mammalian female reproductive axis. $a$, During negative feedback, estrogen uncouples postsynaptic $\mathrm{GABA}_{\mathrm{B}}$ receptors from their effector $\mathrm{K}^{+}$channels in GABAergic POA neurons. This leads to a decreased autoinhibition and an increased inhibitory tone onto GnRH neurons, thereby reducing GnRH release and ultimately $\mathrm{LH}$ secretion. $b$, During positive feedback, estrogen decreases POA GAD expression, thereby diminishing intraneuronal transmitter levels and the release of GABA. This reduces inhibitory GABAergic tone onto GnRH neurons, which facilitates excitatory (e.g., glutamatergic, noradrenergic) inputs in generating the preovulatory $\mathrm{LH}$ surge.

\section{GABAergic neurons are a primary target of estrogen's actions in the CNS}

The present results serve to extend our appreciation of the vital importance of estrogen in regulating GABAergic neuronal function in the brain. For example, in the basal ganglia, estrogen rapidly inhibits $\mathrm{Ca}^{2+}$ currents in medium spiny GABAergic neurons (Mermelstein et al., 1996). Estrogen also exerts profound effects on sensorimotor activity and mating behavior that may be related to the uncoupling of the autoreceptor in these neurons (Becker et al., 1987; Xiao and Becker, 1997). Moreover, in hippocampal neurons estrogen reduces GABAergic synaptic currents, a reduction that is associated with increased dendritic spine formation on postsynaptic pyramidal cell membranes (Murphy et al., 1998). Hence, via its actions on GABAergic neurons not only can estrogen profoundly influence reproduction and the basal ganglia's regulation of fine motor control, but estrogen may also impact learning and memory (Fink et al., 1996; Murphy et al., 1998) as well as exert neuroprotective effects (Yang et al., 2000).

In conclusion, we have shown presently that estrogen negatively modulates the $\mathrm{GABA}_{\mathrm{B}}$ receptor-mediated autoinhibition of GABAergic POA neurons in the female guinea pig. This finding provides new insight into the mechanism(s) of steroid-induced negative feedback of the mammalian reproductive cycle. Moreover, the subsequent decrease in the capability of these neurons to synthesize GABA likely serves to promote steroid-induced positive feedback and the associated LH surge (Fig. 7). These effects on GABAergic neurons may help to explain many actions of this pleiotropic hormone in the CNS.

\section{REFERENCES}

Becker JB, Snyder PJ, Miller MM, Westgate SA, Jenuwine MJ (1987)

The influence of the estrous cycle and intrastriatal estradiol on senso- rimotor performance in the female rat. Pharmacol Biochem Behav 27:53-59.

Bon C, Galvan M (1996) Electrophysiological actions of GABA ago- $_{\mathrm{B}}$ nists and antagonists in rat dorso-lateral septal neurones in vitro. $\mathrm{Br} \mathrm{J}$ Pharmacol 118:961-967.

Bowery N (1989) GABA(B) receptors and their significance in mammalian pharmacology. Trends Pharmacol Sci 10:401-407.

Brann DW, Zamorano PL, Putnam-Roberts CD, Mahesh VB (1992) Gamma-aminobutyric acid-opioid interactions in the regulation of gonadotropin secretion in the immature female rat. Neuroendocrinology 56:445-452.

Brown D, Herbison AE, Robinson JE, Marrs RW, Leng G (1994) Modelling the luteinizing hormone-releasing hormone pulse generator. Neuroscience 63:869-879.

Chronwall BM (1985) Anatomy and physiology of the neuroendocrine arcuate nucleus. Peptides 6:1-11.

Commons KG, Kow L-M, Milner TA, Pfaff DW (1999) In the ventromedial nucleus of the rat hypothalamus, GABA-immunolabeled neurons are abundant and are innervated by both enkephalin- and GABAimmunolabeled axon terminals. Brain Res 816:58-67.

Condon TP, Dykshoorn-Bosch MA, Kelly MJ (1988) Episodic luteinizinghormone release in the ovariectomized female guinea pig: rapid inhibition by estrogen. Biol Reprod 38:121-126.

Decavel C, van den Pol AN (1990) GABA: a dominant neurotransmitter in the hypothalamus. J Comp Neurol 302:1019-1037.

Decavel C, van den Pol AN (1992) Converging GABA- and glutamateimmunoreactive axons make synaptic contact with identified hypothalamic neurosecretory neurons. J Comp Neurol 316:104-116.

Donoso AO, López FJ, Negro-Vilar A (1992) Cross-talk between excitatory and inhibitory amino acids in the regulation of luteinizing hormone-releasing hormone secretion. Endocrinology 131:1559-1561.

Fang Y, Rønnekleiv OK (1999) Cocaine upregulates the dopamine transporter in fetal rhesus monkey brain. J Neurosci 19:8966-8978.

Fink G, Sumner BEH, Rosie R, Grace O, Quinn JP (1996) Estrogen control of central neurotransmission: effect on mood, mental state, and memory. Cell Mol Neurobiol 16:325-344.

Goldsmith PC, Thind KK, Song T, Kim EJ, Boggan JE (1990) Location of the neuroendocrine gonadotropin-releasing hormone neurons in the monkey hypothalamus by retrograde tracing and immunostaining. J Neuroendocrinol 2:157-168.

Grattan DR, Selmanoff M (1994) Castration-induced decrease in the activity of medial preoptic and tuberoinf undibular GABAergic neurons is prevented by testosterone. Neuroendocrinology 60:141-149.

Grattan DR, Rocca MS, Sagrillo CA, McCarthy MM, Selmanoff M (1996a) Antiandrogen microimplants into the rostral medial preoptic area decrease $\gamma$-aminobutyric acidergic neuronal activity and increase luteinizing hormone secretion in the intact male rat. Endocrinology 137:4167-4173.

Grattan DR, Rocca MS, Strauss KI, Sagrillo CA, Selmanoff M, McCarthy MM (1996b) GABAergic neuronal activity and mRNA levels for both forms of glutamic acid decarboxylase $\left(\mathrm{GAD}_{65}\right.$ and $\left.\mathrm{GAD}_{67}\right)$ are reduced in the diagonal band of Broca during the afternoon of proestrus. Brain Res 733:46-55.

Hammer RP, Zhou L, Cheung S (1994) Gonadal steroid hormones and hypothalamic opioid circuitry. Horm Behav 28:431-437.

Herbison AE (1997) Estrogen regulation of GABA transmission in rat preoptic area. Brain Res Bull 44:321-326.

Herbison AE, Heavens RP, Dye S, Dyer RG (1991) Acute action of oestrogen on medial preoptic gamma-aminobutyric acid neurons: correlation with oestrogen negative feedback on luteinizing hormone secretion. J Neuroendocrinol 3:101-106.

Herbison AE, Horvath TL, Naftolin F, Leranth C (1995) Distribution of estrogen receptor-immunoreactive cells in monkey hypothalamus: relationship to neurones containing luteinizing hormone-releasing hormone and tyrosine hydroxylase. Neuroendocrinology 61:1-10.

Jarry H, Hirsch B, Leonhardt S, Wuttke W (1992) Amino acid neurotransmitter release in the preoptic area of rats during the positive feedback actions of estradiol on $\mathrm{LH}$ release. Neuroendocrinology 56:133-140.

Jarry H, Leonhardt S, Wuttke W (1995) The inhibitory effect of $\beta$-endorphin on LH release in ovariectomized rats does not involve the preoptic GABAergic system. Exp Clin Endocrinol Diabetes 103:317-323.

Kelly MJ, Wagner EJ (1999) Estrogen modulation of G-protein-coupled receptors. Trends Endocrinol Metab 10:369-374.

Kelly MJ, Loose MD, Ronnekleiv OK (1992) Estrogen suppresses $\mu$-opioid- and $\mathrm{GABA}_{\mathrm{B}}$-mediated hyperpolarization of hypothalamic arcuate neurons. J Neurosci 12:2745-2750.

King JC, Liu E, Ronsheim PM, Slonimski M, Rubin BS (1998) Expression of Fos within luteinizing hormone-releasing hormone neurons, in relation to the steroid-induced luteinizing hormone surge in guinea pigs. Biol Reprod 58:316-322.

Knobil E (1974) On the control of gonadotropin secretion in the rhesus monkey. Recent Prog Horm Res 30:1-36.

Lagrange AH, Rønnekleiv OK, Kelly MJ (1995) Estradiol-17 $\beta$ and 
$\mu$-opioid peptides rapidly hyperpolarize GnRH neurons: a cellular mechanism of negative feedback. Endocrinology 136:2341-2344.

Lagrange AH, Ronnekleiv OK, Kelly MJ (1997) Modulation of G protein-coupled receptors by an estrogen receptor that activates protein kinase A. Mol Pharmacol 51:605-612.

Lanza M, Fassio A, Gemignani A, Bonanno G, Raiteri M (1993) CGP 52432: a novel potent and selective GABA(B) autoreceptor antagonist in rat cerebral cortex. Eur J Pharmacol 237:191-195.

Leranth C, MacLusky NJ, Sakamoto H, Shanabrough M, Naftolin F (1985) Glutamic acid decarboxylase-containing axons synapse on LHRH neurons in the rat medial preoptic area. Neuroendocrinology 40:536-539.

Leranth C, Shanabrough M, Naftolin F (1991) Estrogen induces ultrastructural changes in progesterone receptor-containing GABA neurons of the primate hypothalamus. Neuroendocrinology 54:571-579.

Martin DL, Rimvall K (1993) Regulation of gamma-aminobutyric acid synthesis in the brain. J Neurochem 60:395-407.

Masotto C, Wisniewski G, Negro-Vilar A (1989) Different gammaaminobutyric acid receptor subtypes are involved in the regulation of opiate-dependent and independent luteinizing hormone-releasing hormone secretion. Endocrinology 125:548-553.

Mermelstein PG, Becker JB, Surmeier DJ (1996) Estradiol reduces calcium currents in rat neostriatal neurons via a membrane receptor. J Neurosci 16:595-604.

Misgeld U, Bijak M, Jarolimek W (1996) A physiological role for $\mathrm{GABA}_{\mathrm{B}}$ receptors and the effects of baclofen in the mammalian central nervous system. Prog Neurobiol 46:423-462.

Morrell JI, McGinty JF, Pfaff DW (1985) A subset of $\beta$-endorphin- or dynorphin-containing neurons in the medial basal hypothalamus accumulates estradiol. Neuroendocrinology 41:417-426.

Murphy DD, Cole NB, Greenberger V, Segal M (1998) Estradiol increases dendritic spine density by reducing GABA neurotransmission in hippocampal neurons. J Neurosci 18:2550-2559.

Naftolin F, Leranth C, Horvath TL, Garcia-Segura LM (1996) Potential neuronal mechanisms of estrogen actions in synaptogenesis and synaptic plasticity. Cell Mol Neurobiol 16:213-223.

Párducz A, Perez J, Garcia-Segura LM (1993) Estradiol induces plasticity of GABAergic synapses in the hypothalamus. Neuroscience 53:395-401.

Rönnekleiv OK, Bosch MA, Naylor BR, Kelly MJ (1991) Progonadotropin-releasing hormone synthesis and processing: measurements of mRNA and peptides. Methods Neurosci 5:85-108.

Roselli CE, Horton LE, Resko JA (1987) Time-course and steroid specificity of aromatase induction in rat hypothalamus-preoptic area. Biol Reprod 37:628-633.

Sawaki Y, Yagi K (1976) Inhibition and facilitation of antidromically identified tubero-infundibular neurones following stimulation of the median eminence in the rat. J Physiol (Lond) 260:447-460.
Silverman AJ, Krey LC, Zimmerman EA (1979) A comparative study of the luteinizing hormone releasing hormone (LHRH) neuronal networks in mammals. Biol Reprod 20:98-110.

Sullivan KA, Witkin JW, Ferin M, Silverman A-J (1995) Gonadotropinreleasing hormone neurons in the rhesus macaque are not immunoreactive for the estrogen receptor. Brain Res 685:198-200.

Terasawa E, Wiegand SJ (1978) Effects of hypothalamic deafferentation on ovulation and estrous cyclicity in the female guinea pig. Neuroendocrinology 26:229-248.

Tsai CC, Yen SSC (1971) Acute effects of intravenous infusion of $17 \beta-$ estradiol on gonadotropin release in pre- and post-menopausal women. J Clin Endocrinol Metab 32:766-771.

van den Pol AN, Cassidy JR (1982) The hypothalamic arcuate nucleus of rat: a quantitative Golgi analysis. J Comp Neurol 204:65-98.

Wagner EJ, Bosch MA, Kelly MJ, Rønnekleiv OK (1999) A powerful $\mathrm{GABA}_{\mathrm{B}}$ receptor-mediated inhibition of GABAergic neurons in the arcuate nucleus. NeuroReport 10:2681-2687.

Watson RE, Langub MC, Landis JW (1992) Further evidence that most luteinizing hormone-releasing hormone neurons are not directly estrogen-responsive: simultaneous localization of luteinizing hormonereleasing hormone and estrogen receptor immunoreactivity in the guinea-pig brain. J Neuroendocrinol 4:311-317.

Witkin JW, Ferin M, Popilskis SJ, Silverman A-J (1991) Effects of gonadal steroids on the ultrastructure of $\mathrm{GnRH}$ neurons in the rhesus monkey: synaptic input and glial apposition. Endocrinology 129:1083-1092.

Witkin JW, Xiao E, Popilskis S, Ferin M, Silverman A-J (1994) FOS expression in the gonadotropin-releasing hormone $(\mathrm{GnRH})$ neuron does not increase during the ovarian steroid-induced $\mathrm{GnRH}$ surge in the rhesus monkey. Endocrinology 135:956-961.

Xiao L, Becker JB (1997) Hormonal activation of the striatum and the nucleus accumbens modulates paced mating behavior in the female rat. Horm Behav 32:114-124.

Yagi K, Sawaki Y (1975) Recurrent inhibition and facilitation: demonstration in the tubero-infundibular system and effects of strychnine and picrotoxin. Brain Res 84:155-159.

Yamaji T, Dierschke DJ, Bhattacharya AN, Knobil E (1972) The negative feedback control by estradiol and progesterone of $\mathrm{LH}$ secretion in the ovariectomized rhesus monkey. Endocrinology 90:771-777.

Yang S-H, Shi J, Day AL, Simpkins JW (2000) Estradiol exerts neuroprotective effects when administered after ischemic insult. Stroke 31:745-750.

Yen SSC, Tsai CC (1971) The effect of ovariectomy on gonadotropin release. J Clin Invest 50:1149-1153.

Yen SSC, Tsai CC (1972) Acute gonadotropin release induced by exogenous estradiol during the mid-follicular phase of the menstrual cycle. J Clin Endocrinol Metab 34:298-305. 